\title{
Concept of the urban knowledge. A case of Poland
}

\author{
Katarzyna Marciniak \\ Wroclaw University of Economics \\ ul. Komandorska 118/120, 53-345 \\ Wroclaw, Poland \\ Email: \\ katarzyna.marciniak@ue.wroc.pl
}

\begin{abstract}
This document describes the concept of urban knowledge. Main aim of this paper is to define term, describe assumptions and possibilities of use. The paper consists of introduction, five chapters and the summary. In introduction author presents background of conducted research. First chapter is the explanation of the urban knowledge phenomenon. Second presents further characteristic with brief classification. Later, author presents how urban knowledge can be managed. In the last chapter, author is trying to point possible methods of urban knowledge acquisition based on available ICT solution. In the summary author will describe chances of application for presented model.
\end{abstract}

\section{INTRODUCTION}

A $\mathrm{S}$ the priority issues, which are defined by the National Spatial Development Concept 2030[18]., are considered: the low competitiveness of major urban centers and Polish regions against European, poor territorial cohesion of the country, the low level of infrastructure (especially transport, social, information, including information technology) areas urban and rural areas, the lack of a coherent system of environmental protection, insufficient resistance to the spatial structure of internal and external threats and spatial disorder.

According to the author's knowledge, a key element for the pursuit of development in line with the reasons stemming from the macro-cities is an urban knowledge. Taking into account the results of enterprises market functioning and the results that achieve through the use of knowledge management processes, the author believes that urban knowledge may be an aspect that will allow raising the competitiveness of cities, seeking to ensure the integration of infrastructure (mainly in the area of information technology, social and governance) and achieving spatial cohesion. Thus, the author believes that the improvement of management processes in the cities, on the basis of knowledge can contribute to the real fulfillment of assumptions NSDC 2030 in Poland.

This work was not supported by any organization

\section{II.URBAN KNOWLEDGE DEFINITION}

To be able to explain the urban knowledge concept, it is necessary to localize it roots in the concept of organizational knowledge.

Knowledge is not only one of the most important assets of an organization, but also the basis, the starting point used to define a strategy, especially for the implementation of management information systems. Knowledge, for the purposes of computing is based on data and information, where data is understood as a set of facts, measurements, statistics and information as the structuring of the data. In this sense, knowledge is a set of information that can be used in practice. However, the organization cannot exist without human capital. [9]

In the theory of knowledge management, there is the explicit and discreet knowledge. [6] Explicit knowledge (formal), as general, considers formal documents created by the organization. Discrete knowledge (informal) is defined as skills, qualifications and experience of human capital. This knowledge is not written anywhere, it is in minds of employees, what really constitutes a barrier to obtaining confidential knowledge. However, there are no barriers that cannot be overcome. [4]

In order to ensure the proper transformation of tacit knowledge into explicit one, as the first condition, it has to be pointed and realized by the organizational culture in the enterprise. [2] Secondly human resources have to be ensured in adequate mechanisms of facilitation the knowledge sharing process in a fair and codified why. It is therefore necessary to create appropriate procedures and systems which should enable knowledge capturing, processing and sharing according to requirements. [7] The weak point of this attitude is still the will of the employee, if they wants to share knowledge or not.

What it is the urban knowledge? The spine of the concept is equal to definitions presented above but in authors opinion it is needed to extend the classification.

First, it is needed to distinguish tacit and explicit knowledge of the city, bearing in mind that the city consists of municipal decision-making units and its external and 
internal environment. Therefore, the explicit knowledge of the city can be considered as all kinds of documents, law, statistics, forecasts, reports, documentation, information, demands, portals relevant to public services or stakeholders, available for the public by each of the entities functioning within the city. Whereas the tacit knowledge of the city considers the qualifications, experience, skills, knowledge of both: employees of the administrative and governing units and knowledge of stakeholders, as well as citizens.

To have a comprehensive description of the urban knowledge, presented basics should be extended by several features important from the point of view of tacit knowledge. Urban knowledge is created independently by entities operating both inside and outside the structure of the city. This kind of knowledge must be gathered and stored in a very specific way, which will provide its uniqueness for a long time.

Urban knowledge is created by the local authorities, politicians, social activists, educational institutions, healthcare entities, religious, environmental bodies, research and development, administrative units, business, science, citizens and other stakeholders. According to the model of intelligent city, author decided to classify urban knowledge on six key aspects described in table 1 .

TABLE I.

TYPOLOGY OF URBAN KNOWLEDGE

\begin{tabular}{|l|l|}
\hline \multicolumn{1}{|c|}{$\begin{array}{c}\text { Urban } \\
\text { knowledge } \\
\text { type }\end{array}$} & \multicolumn{1}{|c|}{ Components } \\
\hline $\begin{array}{l}\text { Economical } \\
\text { knowledge }\end{array}$ & $\begin{array}{l}\text { Cooperation, Productivity, Entrepreneurship, } \\
\text { Finance/budgeting, Public relations/marketing, Planning, } \\
\text { Infrastructure }\end{array}$ \\
\hline $\begin{array}{l}\text { Social } \\
\text { knowledge }\end{array}$ & $\begin{array}{l}\text { Social difference and classes, Social problems, Social } \\
\text { needs, Believes }\end{array}$ \\
\hline $\begin{array}{l}\text { Environmental } \\
\text { knowledge }\end{array}$ & $\begin{array}{l}\text { Natural resources, Access to resources, Eco services, } \\
\text { entrepreneurships, Pollution, Environment protection, } \\
\text { Policy of sustainable environment }\end{array}$ \\
\hline $\begin{array}{l}\text { Mobility } \\
\text { knowledge }\end{array}$ & $\begin{array}{l}\text { Services, condition and sources of public transport, } \\
\text { External sources of public transport, Availability and } \\
\text { stability of ICT infrastructure, Transport systems }\end{array}$ \\
\hline $\begin{array}{l}\text { Governance } \\
\text { knowledge }\end{array}$ & $\begin{array}{l}\text { Public and private sector, Citizens involvement, } \\
\text { Suppliers and recipients in decision-making processes, } \\
\text { Clarity of managerial processes, Rules of sustainable } \\
\text { development, Perspective of cities development }\end{array}$ \\
\hline $\begin{array}{l}\text { Quality of life } \\
\text { knowledge }\end{array}$ & $\begin{array}{l}\text { The attractiveness of available objects and events in the } \\
\text { city, region, Health condition, access to medical units, } \\
\text { Safety of residents and businesses, Living conditions, } \\
\text { Education level, Tourist attractiveness,Social cohesion }\end{array}$ \\
\hline
\end{tabular}

All the presented in the table 1 aspects of urban knowledge will be characterized briefly in the next chapter.

\section{THE ESSENCE OF URBAN KNOWLEDGE}

The essence of the urban knowledge is to provide the most comprehensive knowledge of its stakeholder, resources, processes, conditions or predispositions. Proving, that in the context of smart city, transformation of the city is geared strictly to the needs of citizens, can be found in just presented the characteristics of the knowledge city.

\section{A. Economical knowledge}

Category of economical knowledge of the city revolves around the existing cooperation between the city and specific subjects. It focuses on information about potential cooperation, development opportunities, possible investments. Collaborations, which in the past have produced adverse effects are included as well. An important point of economic knowledge is also a problem of productivity of the city. It is not just about the number and quality of public services provided, but also about the knowledge associated with the ability of the city to meet the needs of its residents. The productivity of the city is an indicator of the level of wages, benefits, profits, and taxes provided for urban residents. Knowledge of entrepreneurship in the city is the basis for defining, classifying the level and direction of development of the city.

\section{B. Environmental knowledge}

Urban knowledge also focuses on the area related to the natural environment. "Talking about the natural environment of the city is so reasonable that urban development and functioning of the technical infrastructure largely transformed original, natural conditions and makes the individual elements of the natural environment in the city acquire specific characteristics." In this regard, the managers are obliged to collect and update the knowledge on natural resources and access to these resources. Ecological services available in the city needed to be implemented.

\section{Mobility knowledge}

Mobility of the city is also important for defining the urban knowledge. It is a very difficult area of decisionmaking for the city. Very often the local authorities must make decisions based on conflict of information or conflict of society needs or both of them in the same time. In order to facilitate a process of planning and then implementing solutions in due to meet the needs of society, it is important to acquire, collect and use of information and knowledge related to public transport services, its technical condition and possible alternatives in the form of external transport services. As well, access and the stability of ICT infrastructure supporting the management of transport and traffic in cities became crucial. Gathering such knowledge, and its subsequent use is mainly aimed at meeting the needs of ensuring a well-functioning, safe and optimal public transport in the city.

\section{D.Managerial knowledge}

Knowledge management within the city has to be concerned with the transparency of management processes, functioning on the basis of rational, prospects for the development of the city and make rational decisions based on their knowledge and experience. The source of such knowledge are certainly laws, their distribution task for all public administrations and local self-government, participation of citizens in the process of creating a vision 
and strategy for the city, the characteristics of private and public sector, suppliers and recipients in decision-making and knowledge about the condition of the city, held resources and needs to meet. Possession of such knowledge by policymakers in the city can provide an excellent basis for constructing a holistic view on some issues, including defining the correct relationships of cause and effect.

\section{E. Social and quality of life knowledge}

Each of the six selected aspects of the urban knowledge concerns directly or indirectly on social layer. However, in the authors opinion, two aspects - social and quality of life knowledge, speak directly about the needs of the residents of the city.

\section{URBAN KNOWLEDGE MANAGEMENT}

Knowing that each city of democratic country is obligated to develop and realize their own strategies, especially based on knowledge, it is possible to claim, that urban knowledge management involves the effective use of urban knowledge and transforming it into the lasting value for city's stakeholders and managerial staff. [2], [14] Urban knowledge management is clearly defined and systematic management of dynamic knowledge for the city and its associated processes of creating, gathering, organizing, diffusion, use and exploitation of knowledge, carried out in pursuit of the objectives of the city. [16]

Urban knowledge management can be also treated as a specially designed system that helps cities to acquire, analyse the use (re-use) of urban knowledge in order to make faster, smarter and better decisions, so that they can achieve a competitive advantage in case of covering cities stakeholders needs. [10] Urban knowledge management covers management of information, knowledge and expertise available within the city, i.e. mobility, environment, social, managerial, economical by the creation, collection, storage, sharing and use, to ensure the cities future development based on well prepared decision plans. Urban knowledge management deliberates cities strategy, which selects, distils, stores, organizes, packs and provides information relevant to the cities stakeholders in a way that improves efficiency and competitiveness of the city in the end. [5], [3]

A properly selected integrated management information system now enables the efficient management of the entire city, carrying out city's management functions with regard to both its internal environment and external, and thus, proper management of urban knowledge. "The selection of specific solutions and technologies in the field of urban knowledge management in the city should be carried out depending on the specifics of the city, its profile, individual economic situation, its strategy and approach to knowledge management. Each city or its institution should be regarded as an organization with its characteristic organizational culture, creative employees, principles and standards prevailing within it and look at it through the prism of ongoing business processes. In addition, each city must be aware that the overall urban knowledge management system cannot be based only on properly chosen technology" [17].

Resource management of urban knowledge, with respect to the characteristics presented in the article, the requirements of the assumptions Knowledge Based Economy or observable development solutions, can be supported by specialized tools of ICT dedicated for the specified area. As the main tasks carried out, supported by solutions that support urban knowledge management, include[1], [14]:

- the acquisition of knowledge from a variety of, often heterogeneous resources,

- creating and coding different elements of urban knowledge in order to incorporate them into basic information system in the city,

- supporting the exchange of urban knowledge and providing comprehensive operation of teamwork.

These examples of tasks supported by dedicated tools for urban knowledge management include: distribution of documents and their monitoring, defining and monitoring over the course of project implementation, communication between stakeholders and cities management, workflow control and monitoring of teamwork. Knowledge in these tools is treated very flexibly - starting with the classification of unstructured documents and finishing on the formal knowledge bases [11], [12].

\section{ACQUISITION OF URBAN KNOWLEDGE}

Ensuring constant contact with the public by means of ICT solutions, e.g. knowledge exchange platform, can contribute to enhance the competitiveness of the city, leveling of social inequalities, mitigate conflicts, alleviate the problems of infrastructure, economic, or investment. In addition, it will help to ensure consistency of information in the city.

As the purpose of the existence and operation of ICT infrastructure in the city is the integration of key information generated by its users, which provide a complete list of requirements, guidelines for maintenance and improvements in many aspects, including those associated with improving the quality of life by better knowledge management in the city. Because of this, it is a smart city project, the concept of a better life for the citizens, there is nothing surprising in fact, that talks about the need for citizens:

- a comprehensive contact, including the implementation of intelligent technology and information resources public, allowing the systematization and increase citizens' access to information and knowledge of using ICT infrastructures,

- full integration, assuming that the basic infrastructure scheme operating system of the target group heterogeneous information generated by specific entities are together entirely integrated into a single portal for example, and the assistance available to the presentation layer, respectively specific audiences, 
- incentives for innovation (called encouragement for innovation), covering all the action of the city authorities for enterprises and public institutions, in order to propagate their use of new technologies as a means of enabling equality technological society,

- collaboration (called collaborative operation), based on intelligent infrastructure, critical systems and cooperating users (including public bodies, local authorities, professionals, non-governmental bodies, excluded people, etc.), which helps to improve effectiveness in the developing the public services.

Presented solution enables the integration of the information needs of citizens and all the entities interested.

For platform users, platform becomes a compendium of knowledge about the urban knowledge (economy, people, environment, mobility, governance, living).

As we can see, ensuring citizens by the city's authorities can contribute to the objectives of the NSDC 2013, which points combating low competitiveness of major urban centers and Polish regions against European, poor territorial cohesion of the country, low level of infrastructure (especially transport, social, information, including information technology) urban and rural areas, the lack of a coherent system of environmental protection, insufficient resistance to the spatial structure of internal and external threats and spatial disorder.

\section{CONCLUSION}

Proposed in the paper approach with use of ICT solutions to gather urban knowledge, is unfortunately so idyllic that it does not take into account the problems which for centuries is faced by all cities of the world, i.e. excluded, homeless, not involved in the social life of the city, the mismatch solutions to the needs of users, lack of willingness to change thinking among municipal authorities, resistance among employees of local government, political, economic phenomena robbery, the gray zone, the fear of citizens, and cyber security.

Of course, each of these problems are trying to be solved by finding and implementing various solutions, but it not always provide the desired effect. On the other hand, not handling problems in case of improving quality of lives most of citizens by authorities would be a crime, which is governed in Poland by the Criminal Code (intentional act to the detriment of the customer, citizen, entity). As we can see, the decisions of investment and development in cities do not belong to the easiest. Their implementation is also not trivial.

However, author believes that the reestablishment of order and consistency in the city's functioning should be a top priority for the governments of each city in Poland. We have to remember also, that attempts of achieving it are determined by current investment decisions and made improvements. Therefore, it is essential that all urban transformation which are going to happen should include the use of information and communication technologies, systems operating in harmony and in favor of the environment and conducting researches on city's sustainable development based on knowledge.

Described in the paper concept of the urban knowledge provides the basis for further consideration on city's development determined by new management techniques. To produce a resource in the form of urban knowledge is not only to achieve positive economic impact on the city, region, or country but mainly aims to prepare themselves to meet the future needs of civilization, currently generated by the society, classified as information. In the information society the dominant role plays nothing else but knowledge. That why every city in Poland, according to the author assumptions, should seek to create, to clarify their urban knowledge. Especially, when it is in line with the objectives of knowledge management. It means, that city can contribute to make better decisions, accelerate information processes, reduce unnecessary costs, increase satisfaction or level citizens' lives quality.

\section{REFERENCES}

[1] Albescu F., Pugna I., Paraschiv D., Business Intelligence \& Knowledge Management - Technological Support for Strategic Management in the Knowledge Based Economy, Revista Informatica Economica, no 4(48)/2008

[2] Albescu F., Pugna I., Paraschiv D., Cross-cultural Knowledge Management, Informatica Economica vol.13, no 4/2009

[3] Baltzan P., Phillips A., Business Driven Information Systems, second edition, McGraw-Hill Irwin, New York 2009

[4] Bergeron B.m Essentials of Knowledge Management, John Wiley \& Sons, New Jersey 2003

[5] Błaszczuk A., Brdulak J.J., Guzik M., Pawluczuk A., Zarządzanie wiedzą w polskich przedsiębiorstwach,Szkoła Główna Handlowa, Warszawa 2004

[6] Global Footprint Network http://www.footprintnetwork.org/en/index.php/GFN/page/frequently_ asked questions/ [2015-03-15]

[7] Jakubczyc J., Mercier-Laurent E., Owoc M.L : What is Knowledge Management? Baborski A. (red.). Research Paprers of Wrocław Economic Academy no 815, Wrocław 1999

[8] Jakubowski T., Zarządzanie wiedzą w firmach konsultingowych, Gazeta IT nr 7, listopad 2002

[9] Karamalla-Gaiballa E., Matouk K., Zarządzanie wiedzą w przedsiębiorstwie a jego potencjał ludzki:

[10] Marciniak K., Owoc M., Knowledge Management in the Interactive Portal for Decision Makers on InKOM Example, INTERNATIONAL SCIENCE INDEX 9(1) 2015, eISSN: 1307-6892, p.705-712

[11] Nycz M., Business Intelligence in Enterprose 2.0 in Knowledge Acquisition and Management no 232 Research Papers of Wrocław University of Economics, Publishing House of Wrocław University of Economics, Wrocław 2010, ISSN 1899-3192

[12] Richard T. Herschel and Nory E. Jones, Knowledge management and business intelligence: the importance of integration, in JOURNAL OF KNOWLEDGE MANAGEMENT VOL. 9 NO. 4 2005, Emerald Group Publishing Limited, ISSN 1367-3270

[13] Skyrme D.J., Knowledge Networking. Creating the Collaborative Enterprise, Butter-worth-Heinemann, Oxford 1999

[14] Tiwana A., The knowledge management toolkit, PTR 1999

[15] Turban E., Leidner D., Mclean E., Wetherbe J., Information Technology for Management Transofrming Organizations in Digital Economy, 6th edition, John Wiley \& Sons, 2008

[16] R. Żubera R, S. Sudak (red.), „Koncepcja Przestrzennego Zagospodarowania Kraju 2030", Ministerstwo Rozwoju Regionalnego, Warszawa 2012

[17] Cambridge, MA Rep. ARCRL-66-234 (II), 1994, vol. 2. 